\title{
Morphometric variability of wild honey bees of the mountain forest zone of Crimea as a material for breeding
}

\author{
$T O$ Bykova ${ }^{1, *}, A S$ Krivozubov ${ }^{1}, A V$ Ivashov $^{1}, V N$ Sattarov $^{2}, A F$ Safonkin $^{3}, T A$ \\ Triseleva $^{3}, A M$ Soloviev $^{1}$, and $I S$ Emirsinov ${ }^{4}$ \\ ${ }^{1}$ V. I. Vernadsky Crimean Federal University, Pr. Vernadsky, 4, 295007, RussiaRepublic of Crimea, \\ Simferopol, Russia \\ ${ }^{2}$ Bashkir State Pedagogical University named after M. Akmulla, 3-a Oktyabrskoj revoljucii St., \\ 450008, Ufa, Russia \\ ${ }^{3}$ A.N. Severtsov Institute for Ecology and Evolution of RAS, Pr Leninskij, 33, 119071, Moscow, \\ Russia \\ ${ }^{4}$ Nursery "Orekhovod - practitioner", Lenin Street, 31, 298471, village Tankovoe, Bakhchisaray \\ District, Republic of Crimea
}

\begin{abstract}
The results of studies of worker honey bees (Apis mellifera L.) from two points are presented: from a bee colony captured near the Tankovoye village (this swarm was found by a local resident - an entrepreneur, the owner of the private nursery "Orekhovod - practitioner" I.S. Emirsinov) and bees captured in the vicinity of Sugut-Oba mountain (Burus) from a swarm captured about $25 \mathrm{~km}$ to the southeast of Belogorsk and west of the Feodosia height. Measurements of morphometric features were carried out using the method of V.V. Alpatov (1948), the method of F. Ruttner (2006) was used to identify the morphotypes and the width of the hairline of worker bees. The phenotypic homogeneity of bee colonies from the Tankovoye village was revealed by morphotypes and the width of the hairline on the abdomen of worker bees in the presence of a variety of classical morphometric characters. At the same time, one phenotype characterized by morphotype $\mathrm{O}$ (light brown coloration of chitinous integuments on the abdomen) and a narrow hairline $f$ was registered. The presence of this phenotype characterizes the compliance with the breed standards of Apis mellifera caucasica (gray mountain Caucasian), Apis mellifera carpatica (Carpathian) or Apis mellifera carnica (Carniolan), i.e. breeds with a gray abdomen. Molecular genetic analysis of the mtDNA COI site showed the homogeneity of the sample of wild bees captured near the Tankovoye village and their proximity to the Vuchkovskaya line of the Carpathian breed.
\end{abstract}

\footnotetext{
*Corresponding author: t.o.bykova@ mail.ru
} 


\section{Introduction}

Various studies show that the use of local populations of honey bees provides a higher chance of survival, while the use of non-locally adapted honey bees leads to high colony losses, as has been observed recently in many regions of Europe [1-6].

Large-scale migratory beekeeping and queen trade, combined with the erratic mating system of indigenous European bees, leads to increased introgressive hybridization with controlled non-native subspecies, which can lead to the loss of valuable combinations of features formed by natural selection [7-11].

To preserve populations of honeybees, it is necessary to understand the extent to which local populations are genetically isolated. However, when rare populations are threatened with hybridization with closely related taxa, effective containment measures are imperative for their successful conservation [12].

Successful selection and breeding work largely depends on the choice of source material. Russia has several bee breeds and populations formed in specific natural and climatic conditions under the long-term influence of natural selection and a certain impact of mass selection [13]. However, on the Crimean Peninsula, the study of the state of the honey bee population has begun relatively recently. Research has been carried out in the field of morphology, biology, ecology, and genetics, which are currently being carried out singly in local territories [14].

Prior to this, the only material that belongs to the first half of the last century is the monographic work of V.V. Alpatov, where he wrote that a bee lives on the southern coast of Crimea, who deserves to be isolated into a special subspecies or breed. In 1938, in the work "On the cognition of the variability of the honey bee. VI. Bees of the Carniola and Crimea and their place among other forms of Apis mellifera L.", he published data on the biometrics of the Crimean bee collected from primitive flow hives in apiaries in the Baydar Valley. Summing up, the author noted that the isolation of the distribution of bees, the 'island' location, give reason to consider the bee of the southern coast of Crimea as a special subspecies named Apis mellifera taurica Alpatov, 1935. Further, from a chronological point of view, studies related to the search for aboriginal bees belong to the Department of Ecology and Zoology of the V.I. Vernadsky Crimean Federal University. From the archival materials of the department it is known that in 1997 point studies were carried out on the territory of the Mountain Crimea, and at the same time, three families of aboriginal bees were registered in the forest [14].

Thus, it is possible that it is in the remote mountain-forest regions of Crimea, relatively isolated from the main gene flows of imported bee breeds, that unique genotypes and, accordingly, phenotypes that provide adaptations to survival in Crimean conditions have formed over the past 30-40 years. Various breeds were certainly mixed in this territorially small 'cauldron', and drones of different breeds probably contributed to this process to a greater extent, because it is known that the latter can migrate cover distances of 5-7 km.

In view of the above, it is of interest to identify the reserves of bee colonies of the aboriginal group and determine their morphometric and genetic characteristics.

\section{Materials and methods of research}

The object of the study was a sample of worker bees from two places quite remote from rural apiaries. The first sample of 32 bees was selected from a bee colony living in a rock cavity about 2 kilometers from the northern outskirts of the Tankovoye village, ArmanKaya mountain (Crocodile) (Bakhchisaray region, Republic of Crimea). The geographic location and general view of the area can be seen in fig. 1 and 2, respectively. A climber removed several dozen bees on a piece of beeswax with brood. On the map of Crimea in 
the presented fig. 1, this place is marked with a purple dot. This wild family was discovered and watched by a local resident - an entrepreneur and owner of the private nursery "Orekhovod - practitioner" I.S. Emirsinov. The second sample of 23 bees was obtained by a graduate student of the V.I. Vernadsky Crimean Federal University Soloviev A.M. by catching wild worker bees in the forest glades of the protected forest area in the vicinity of Sugut-Oba mountain (Burus), which is about $5 \mathrm{~km}$ from the Zemlyanichnoe village (Belogorsk district, Republic of Crimea). On the map, this place is shown with a red dot (fig. 1), and a general view of the collection site is shown in fig. 3 .

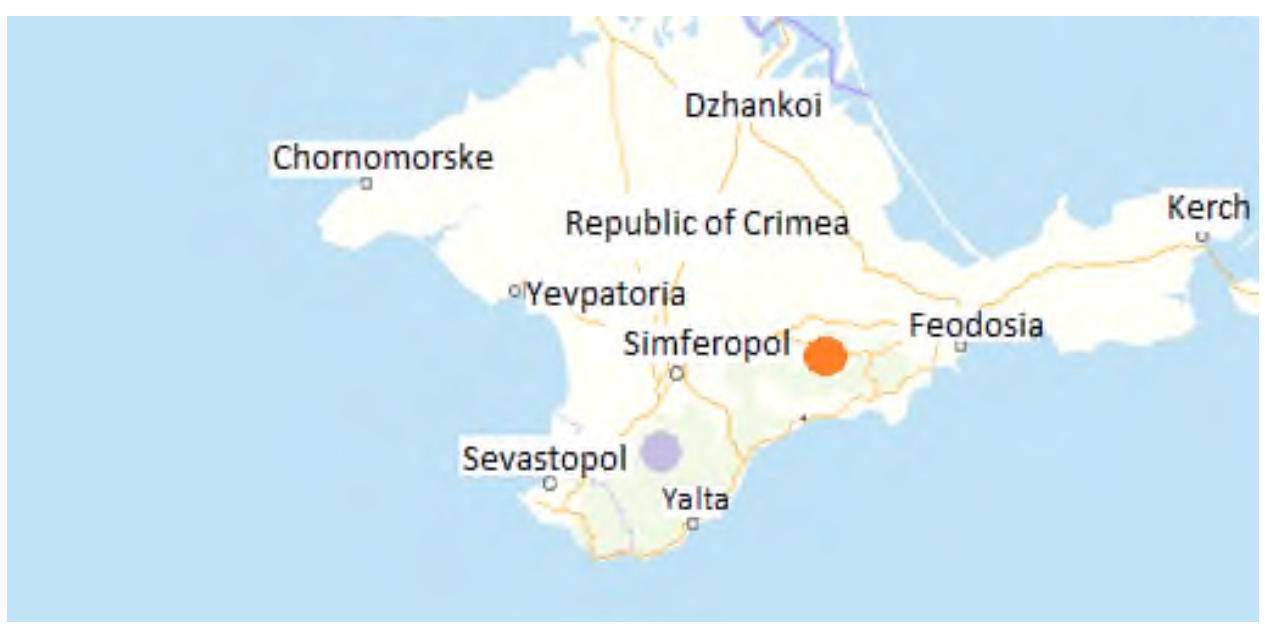

Fig. 1. Geographical map of Crimea with the designation of the territories of the largest settlements:

- a collection point for honey bees on a piece of beeswax with brood near the Tankovoye village, Bakhchisaray region (Arman-Kaya mountain (Crocodile); - the point of catching wild honey bees in the vicinity of Sugut-Oba mountain (Burus), about $25 \mathrm{~km}$ southeast of Belogorsk and west of the Feodosia height.

Fig. 1 shows the sampling sites that are located in the vicinity of the Tankovoye village, Bakhchisaray region (Arman-Kaya mountain, Crocodile), as well as in the vicinity of Sugut-Oba mountain (Burus), about $25 \mathrm{~km}$ southeast of Belogorsk and to the west from the Feodosia height (fig. 2).

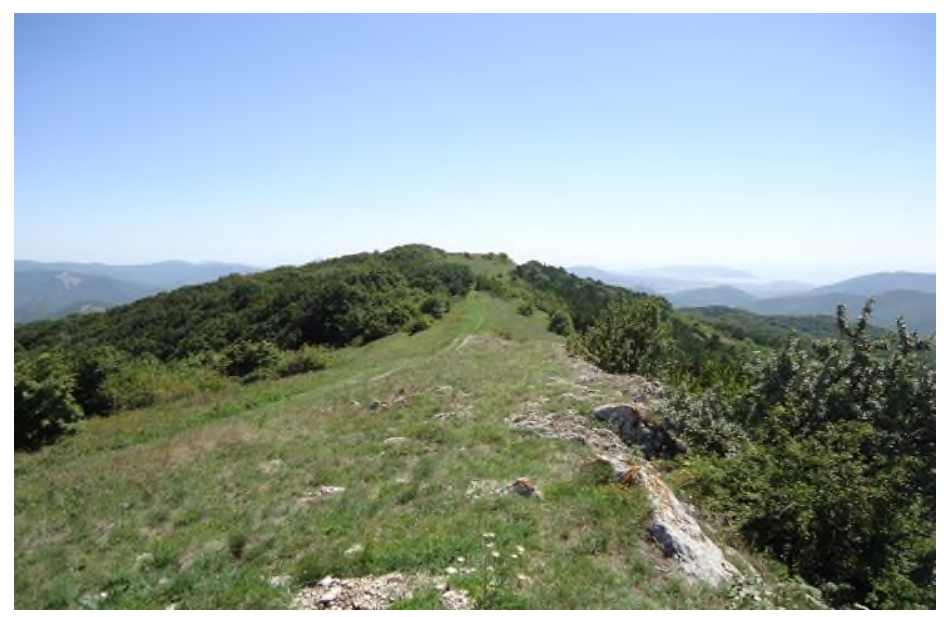

Fig. 2. Sugut-Oba mountain (Burus), about $25 \mathrm{~km}$ southeast of Belogorsk and west of the Feodosia height (photo by A.M. Solovyov). 
The first samples for taxonomic identification were taken from a bee colony living in a rock cavity about 2 kilometers from the northern outskirts of the Tankovoye village, Arman-Kaya mountain (Crocodile) (Bakhchisaray region, Republic of Crimea) (fig. 3).

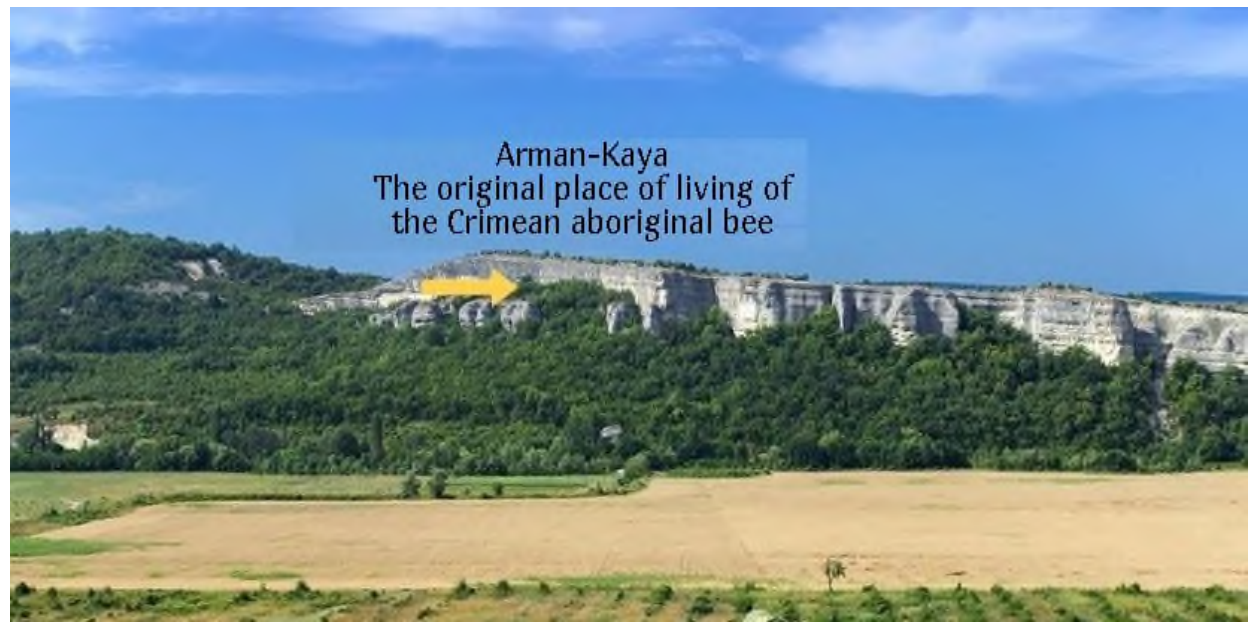

Fig. 3. Arman-Kaya mountain (Crocodile) near the Tankovoye village of the Bakhchisaray district (the arrow indicates the point of catching bees) (photo by I.S. Emirsinov).

Laboratory inspection of samples was carried out at the Department of Ecology and Zoology of the V.I. Vernadsky Crimean Federal University (Simferopol) and the Department of Bioecology and Biological Education of the Bashkir State Pedagogical University named after M. Akmulla (Ufa), Laboratory of Soil Zoology and General Entomology of the Institute of Ecology and Evolution of RAS (Moscow).

Measurements of morphometric features (proboscis length $(\mathrm{mm})$, cubital index (\%), discoidal displacement, length and width of the first segment of the hind tarsus (mm), tarsal index (\%), length and width of the right fore wing $(\mathrm{mm})$ ) were carried out according to the generally accepted method. When carrying out morphometric measurements, an eyepiece micrometer of an MBS-10 stereoscopic microscope was used. Filming was carried out using a Canon EOS550D camera at maximum camera magnification of 281x289 dots. Statistical data processing was carried out in Microsoft Office Excel, 2007.

The classes of morphotypes and the width of the hairline on the abdomen of worker bees were identified by the method of F. Ruttner (2006). The definition of classes of morphotypes was carried out by the color of the chitinous cover: $\mathrm{O}$ (completely dark cuticle, without brown or yellow corners); e (small brown or yellow corners on the cuticle, up to $1 \mathrm{~mm} 2$ ); E (large brown or yellow corners on the cuticle, from $1 \mathrm{~mm} 2$ ); $1 \mathrm{R}$ (one brown or yellow ring on the cuticle); $2 \mathrm{R}$ (two brown or yellow rings on the cuticle); $3 \mathrm{R}$ (the main three brown or yellow rings are on the cuticle). Estimation of the width of the hairline on the abdomen of worker bees was carried out along the middle hairline, on the fourth abdominal segment. According to F. Ruttner (2006), four classes are distinguished: f narrow, ff - medium, F - wide, FF - with an additional border on the second segment.

To carry out morphometric measurements, live bees were treated with ammonia in a killing jar (solution for external use and inhalation 10\%) [15]. Then they were removed and placed in containers with $70 \%$ ethyl alcohol. with a simple pencil, the number of the bee colony and the date of sampling were recorded on a piece of paper, which was placed in the same container. The container was carefully sealed to prevent evaporation of the preservative liquid and the possibility of long-term storage [16]. 
Taxonomic identification of honey bees by cuticle coloration was carried out on dry objects previously prepared as entomological collections. The killing of bees was carried out in a jar for killing insects 'charged' with a $10 \%$ ammonia solution. An ordinary widemouth jar (0.5 1 capacity) with a tight-fitting lid to prevent evaporation was used. Cotton wool was fixed under the lid, on which the corresponding solution was applied. The bees were euthanized within about 30 minutes. Subsequently, the insects were shaken out of the jar and pierced with an entomological pin No. 2 (manufactured by ENTO SPHINX s.r.o., Czech Republic) in the thoracic region in accordance with the entomological requirements for insect decoration.

For long-term storage of worker bees, labeling was carried out (design of labels for pricked insects indicating the location (selection), time, full name of, and all available additional data).

Molecular genetic analysis. For molecular genetic analysis, common DNA was isolated from the tarsus of the imago of worker bees using Diatom 200 reagents (Izogen, Moscow). Amplification was performed using a 5xMasterMix PCR kit (Dialat, Moscow). The analyzed fragment of the mtDNA COI gene was $680 \mathrm{bps}$. To amplify this region, primers LCO1490 and HCO2198 were used for the initial region of the COI gene according to the protocol [17].

The amplification product was purified by precipitation with an ethyl alcohol solution with the addition of $5 \mathrm{M}$ sodium acetate. Electrophoresis and reading of the nucleotide sequences of the amplification product were performed on an ABI PRISM 3130 automatic sequencer (Applied Biosystems, USA) using a BigDye Terminatot kit 3.1 (Applied Biosystems) in the molecular diagnostic methods room at the Institute of Ecology and Evolution of RAS.

The data were processed using the MEGA 5 [18] and Network ver. 4.6.1.1 software packages.

\section{Results and their discussion}

The results of morphometric studies of bees from the rocky cavity of Arman-Kaya mountain are presented in Table 1.

Table 1. Indicators of morphometric measurements of worker bees of a bee colony living in a rock cavity about 2 kilometers from the northern outskirts of the Tankovoye village, Arman-Kaya mountain (Crocodile) (Bakhchisaray district, Republic of Crimea), $n=32$ individuals.

\begin{tabular}{|c|c|c|c|c|c|}
\hline \multirow{2}{*}{ No. } & \multirow{2}{*}{ Sign } & \multirow{2}{*}{$\begin{array}{l}\text { Mes. } \\
\text { unit }\end{array}$} & \multicolumn{3}{|c|}{ Obtained measurements } \\
\hline & & & $\lim$ & $M \pm m$ & $\mathrm{Cv}, \%$ \\
\hline 1 & Proboscis length & $\mathrm{mm}$ & $6.2-6.9$ & $6.60 \pm 0.035$ & 3.03 \\
\hline 2 & $\begin{array}{c}\text { Right shin } \\
\text { length }\end{array}$ & $\mathrm{mm}$ & $4.0-4.5$ & $4.29 \pm 0.026$ & 3.50 \\
\hline 3 & Right shin width & $\mathrm{mm}$ & $2.3-2.6$ & $2.43 \pm 0.012$ & 2.67 \\
\hline 4 & $\begin{array}{l}\text { Right fore wing } \\
\text { length }\end{array}$ & $\mathrm{mm}$ & $9.4-10.5$ & $9.43 \pm 0.358$ & 21.42 \\
\hline 5 & $\begin{array}{l}\text { Right fore wing } \\
\text { width }\end{array}$ & $\mathrm{mm}$ & $6.0-6.5$ & $6.48 \pm 0.084$ & 7.25 \\
\hline 6 & $\begin{array}{c}\text { Discoidal } \\
\text { displacement }\end{array}$ & $\%$ & \multicolumn{3}{|c|}{$《+»-46.87 \% ; 《 0 »-37.5 \% ;\langle-»-15.62 \%$} \\
\hline 7 & Cubital index & $\%$ & $34.88-62.5$ & $46.97 \pm 1.170$ & 14.09 \\
\hline 8 & Tarsal index & $\%$ & $53.33-60.0$ & $56.84 \pm 0.302$ & 2.99 \\
\hline
\end{tabular}

A wide range of lim parameters was observed in terms of proboscis length. The minimum value $(6.2 \mathrm{~mm})$ correlated with the standard $(5.8-6.4 \mathrm{~mm})$ of A. mellifera mellifera (Central Russian breed). The maximum lim value corresponded to the taxonomic 
requirements of the following breeds: A. mellifera caucasica (gray mountain Caucasian) (standard 6.7-7.2 mm), A. mellifera remipes (yellow Caucasian) (standard 6.5-6.9 mm), A. mellifera carpatica (Carpathian) $(6.3-7.0 \mathrm{~mm})$. A similar situation was observed for the mean value of the proboscis length of $A$. mellifera, i.e. compliance with the standards of various breeds - yellow Caucasian, Carpathian, A. mellifera acervorum (Ukrainian steppe) (standard 6.3-6.7 mm), A. mellifera ligustica (Italian) (standard 6.4-6.7 mm), A mellifera carnica (Carniolan) (standard 6.4-6.8 mm) [19].

Along the wing length, the indices of the mean and minimum lim correlated with the standards of the following breeds: Central Russian (9.1-9.6 mm), gray mountain Caucasian (9.1-9.5 mm) and Carpathian (9.3-9.6), respectively.

The maximum indicator of the limit met the requirements of the Carpathian breed, because according to experts, this taxonomic group is characterized as long-winged in comparison with other breeds. At the same time, they note that the wing length can reach $10 \mathrm{~mm}$.

The width of the right fore wing of the bees did not correspond to any breed standard, namely: Ukrainian steppe - $3.2 \mathrm{~mm}$, Central Russian - 2.9-3.3 mm, gray mountain Caucasian and Carpathian breeds - 3.0-3.4 $\mathrm{mm}$.

In terms of discoidal displacement in the analyzed sample, such bees were dominant, whose standard characteristics are closer to the Carpathian ("+" - 80-100\%, "0" - 0-20\%, "-" - 0-5\%) and Ukrainian steppe (" + "- 60 - 65\%," 0 "- 20-30\%," - "- 5-10\%) breeds.

According to the cubital index, there was a significant shift in the mean value $(46.97 \pm$ 1.170) from the maximum indicator of the limit (62.5\%). At the same time, considering the minimum and maximum values of this indicator in bees in the sample, it can be noted that the first indicators did not correspond to the standards of any breed (gray mountain Caucasian breed - 50-55\%, yellow Caucasian breed - 50-55\%, Carpathian breed $-45-50 \%$, Ukrainian steppe breed - 55-60\%, Carniolan breed - 45-50\%, Italian breed - 40-45\%), and according to the maximum value, they corresponded to the Central Russian breed (standard $60-65 \%)$. According to the average value of the cubital index, one can note their compliance with the standards of the Carpathian (45-50\%) and Carniolan (45-50\%) breeds.

The minimum $(53.33 \%)$ and maximum values $(60 \%)$ of the tarsal index limit did not correspond to the officially recognized breed standards: Central Russian breed - $55 \%$, Ukrainian steppe - 56\%, gray Caucasian mountain - 58-59\%, and yellow Caucasian breed $58-59 \%$. At the same time, the average value $(56.84 \%)$ could be correlated with the standard of the Ukrainian steppe breed (56\%).

The results of morphometric studies of wild worker bees caught in the forest glades of the protected forest area in the vicinity of Sugut-Oba mountain (Burus) (Belogorsk district, Republic of Crimea) are presented in Table 2. 
Table 2. Indicators of morphometric measurements of wild worker bees caught in the forest glades of the reserved forest massif in the vicinity of Sugut-Oba mountain (Burus) (Belogorsk district,

Republic of Crimea), $\mathrm{n}=23$ individuals.

\begin{tabular}{|c|c|c|c|c|c|}
\hline \multirow{2}{*}{ No. } & \multirow{2}{*}{ Sign } & \multirow{2}{*}{$\begin{array}{c}\text { Mes. } \\
\text { unit }\end{array}$} & \multicolumn{3}{|c|}{ Obtained measurements } \\
\hline & & & $\lim$ & $M \pm m$ & $\mathrm{Cv}, \%$ \\
\hline 1 & Proboscis length & $\mathrm{mm}$ & $6.0-6.7$ & $6.42 \pm 0.037$ & 2.49 \\
\hline 2 & Right shin length & $\mathrm{mm}$ & $3.8-4.4$ & $4.09 \pm 0.028$ & 2.93 \\
\hline 3 & Right shin width & $\mathrm{mm}$ & $2.0-2.4$ & $2.35 \pm 0.019$ & 3.61 \\
\hline 4 & $\begin{array}{l}\text { Right fore wing } \\
\text { length }\end{array}$ & $\mathrm{mm}$ & 7.6-8.6 & $8.2 \pm 0.100$ & 5.73 \\
\hline 5 & $\begin{array}{l}\text { Right fore wing } \\
\text { width }\end{array}$ & $\mathrm{mm}$ & $4.0-4.5$ & $4.25 \pm 0.040$ & 4.0 \\
\hline 6 & $\begin{array}{c}\text { Discoidal } \\
\text { displacement }\end{array}$ & $\%$ & \multicolumn{3}{|c|}{$\begin{array}{ll}\langle(+»-31.25 \% ; & \ll 0 »-46.87 \% ; \\
& 21.87 \% \\
\end{array}$} \\
\hline 7 & Cubital index & $\%$ & $\begin{array}{l}27.27- \\
51.42\end{array}$ & $41.00 \pm 1.240$ & 13.41 \\
\hline 8 & Tarsal index & $\%$ & $\begin{array}{l}47.61- \\
63.15\end{array}$ & $57.48 \pm 0.660$ & 5.08 \\
\hline
\end{tabular}

Indicators of the length of the proboscis of bees in this sample were characterized by lower values. As in the previous sample, the minimum value of $\lim (6.0 \mathrm{~mm})$ correlated with the standard (5.8-6.4 mm) of the Central Russian breed. The maximum value of lim corresponded to the taxonomic requirements of the following breeds: gray mountain Caucasian (standard 6.7-7.2 mm), yellow Caucasian (standard 6.5-6.9 mm), Carpathian (6.3-7.0 mm), and Ukrainian steppe (standard 6.3-6.7 mm) [19].

A similar situation was observed for the mean value of the proboscis length of $A$. mellifera, i.e. compliance with the standards of various breeds - Carpathian, Ukrainian steppe (standard 6.3-6.7 mm), Italian (standard 6.4-6.7 mm), Carniolan (standard 6.4-6.8 $\mathrm{mm})$.

The results of laboratory inspection along the length and width of the right fore wing make it possible to note that they do not correspond to existing standards (the standard of wing length for bees of the Ukrainian steppe breed is $9.1 \mathrm{~mm}$, for the Central Russian breed - 9.1-9.6 mm, for the gray mountain Caucasian breed - 9, 1-9.5 mm, Carpathian - 9.3-9.6 $\mathrm{mm}$ : the standard for the wing width of Ukrainian steppe bees is $3.2 \mathrm{~mm}$, Central Russian 2.9-3.3 mm, gray mountain Caucasian and Carpathian breeds - 3, 0-3.4 mm).

In terms of the dominance of the indices of discoidal displacement, the bees in the samples did not correspond to the accepted breed standards.

The cubital index showed a wide range between the minimum (27.27\%) and maximum $(51.42 \%)$ values of the limit. At the same time, the minimum value of the limit did not correspond to the accepted breed standards. The maximum value corresponded to the standards of the gray mountain Caucasian and yellow Caucasian breeds. As for the average value of the cubital index, it is possible to note its compliance only with the standard of the Italian breed (40-45\%).

As in the first sample, the minimum (47.61\%) and maximum values $(63.15 \%)$ of the tarsal index limit did not correspond to the officially recognized breed standards: Central Russian breed - 55\%, Ukrainian steppe - 56\%, gray Caucasian mountain - 58- 59\% and yellow Caucasian breed $-58-59 \%$. A similar situation was observed for the average value (57.48\%).

Subsequently, the phenotypic assessment of bees in the samples was carried out. At the same time, we registered one phenotype characterized by morphotype $\mathbf{O}$ (light brown coloration of chitinous integuments on the abdomen) and a narrow hairline f (fig. 4). The presence of this phenotype characterizes the compliance with the breed standards of gray mountain Caucasian, Carpathian or Carniolan bees, i.e. breeds with a gray abdomen. 


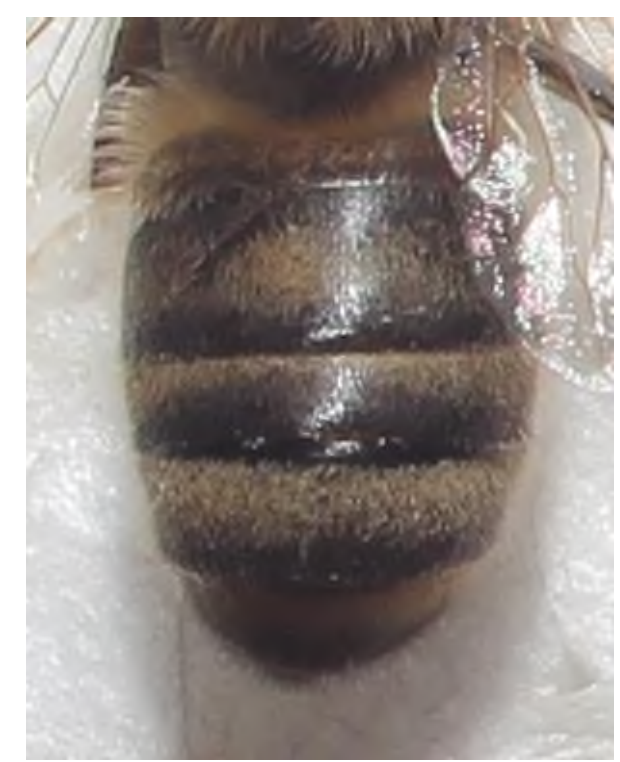

Fig. 4. Phenotype of worker bees $\mathrm{O}(\mathrm{c})-\mathrm{f}$.

A.V. Borodachev with co-authors wrote that when choosing the starting material for the preservation and breeding improvement of bees, it is important to control their genuineness of strain [20]. To assign individuals to a specific breed, exterior and behavioral signs are traditionally used, which are assessed by classical methods, as well as molecular genetic ones, respectively. Despite the fact that A.V. Borodachev emphasized that the external exterior signs vary significantly under the influence of the external environment, it is worth noting that the 'pure' taxonomic groups of honey bees correspond to both external morphological or phenotypic and genetic characteristics of this standard. The results of research and comparative analysis of the mtDNA COI locus of worker bees from a swarm caught near the Tankovoye village is presented in table 3.

Table 3. Discovered substitutions in the mtDNA nucleotide sequence of the studied bees.

\begin{tabular}{|c|c|c|c|c|c|c|c|c|c|}
\hline \multirow{2}{*}{$\begin{array}{l}\text { Number of } \\
\text { the nucleotide } \\
\text { pair with the } \\
\text { identified } \\
\text { substitution }\end{array}$} & \multicolumn{6}{|c|}{ Sample number } & \multicolumn{3}{|c|}{ Genbank } \\
\hline & 1 & 2 & 3 & 4 & 5 & 6 & $\begin{array}{l}\text { LO6178 } \\
\quad \text { Apis } \\
\text { mellifera } \\
\text { ligustica } \\
\end{array}$ & $\begin{array}{c}\text { KX819203+AY1 } \\
14466 \text { Apis } \\
\text { mellifera } \\
\text { caucasica } \\
\end{array}$ & $\begin{array}{c}\text { KJ396188- } \\
\text { Apis } \\
\text { mellifera } \\
\text { mellifera } \\
\end{array}$ \\
\hline 4 & $\mathrm{G}$ & $\mathrm{G}$ & G & G & $\mathrm{G}$ & G & $\mathrm{A}$ & $\mathrm{G}$ & $\mathrm{A}$ \\
\hline 96 & A & A & A & A & A & A & A & A & $\mathrm{C}$ \\
\hline 110 & $\mathrm{G}$ & $\mathrm{G}$ & $\mathrm{G}$ & $\mathrm{G}$ & $\mathrm{G}$ & $\mathrm{G}$ & $\mathrm{G}$ & A & $\mathrm{A}$ \\
\hline 111 & $\mathrm{C}$ & $\mathrm{C}$ & $\mathrm{C}$ & $\mathrm{C}$ & $\mathrm{C}$ & $\mathrm{C}$ & $\mathrm{C}$ & $\mathrm{C}$ & $\mathrm{T}$ \\
\hline 144 & $\mathrm{~T}$ & $\mathrm{~T}$ & $\mathrm{~T}$ & $\mathrm{~T}$ & $\mathrm{~T}$ & $\mathrm{~T}$ & $\mathrm{~T}$ & $\mathrm{~T}$ & $\mathrm{C}$ \\
\hline 153 & $\mathrm{C}$ & $\mathrm{C}$ & $\mathrm{C}$ & $\mathrm{C}$ & $\mathrm{C}$ & $\mathrm{C}$ & $\mathrm{C}$ & $\mathrm{C}$ & $\mathrm{T}$ \\
\hline 246 & $\mathrm{C}$ & $\mathrm{C}$ & $\mathrm{C}$ & $\mathrm{C}$ & $\mathrm{C}$ & $\mathrm{C}$ & $\mathrm{C}$ & $\mathrm{C}$ & $\mathrm{T}$ \\
\hline 249 & $\mathrm{C}$ & $\mathrm{C}$ & $\mathrm{C}$ & $\mathrm{C}$ & $\mathrm{C}$ & $\mathrm{C}$ & $\mathrm{C}$ & $\mathrm{C}$ & $\mathrm{T}$ \\
\hline 559 & $T$ & $\mathrm{~T}$ & $T$ & $T$ & $T$ & $T$ & $\mathrm{~T}$ & $T$ & $\mathrm{C}$ \\
\hline Note. C-c & & & & & & & Ianine; G & ank - internationa & base of \\
\hline
\end{tabular}


When comparing the available molecular genetic data on the mtDNA COI site from the NCBI database of the Italian, Caucasian and Central Russian honeybee breeds with the studied group, it can be concluded that the results of morphometric identification are confirmed by genetic studies, i.e. the bees in the sample do not meet the uniform standards of one breed.

To analyze the genetic relationships of the studied bees with the available data, we built a median network visualizing the relationship or genetic relations. To build the median network, we used the previously obtained sequences of samples of honey bees from different regions of Crimea, bees of the Carpathian race of the Vuchkovskaya line [17, 21], and bees from the present sample from a swarm caught near the Tankovoye village. For comparison, bees of the Caucasian breed were taken from the apiary hive of the private nursery "Orekhovod - practitioner". The median network is represented by several haplotypes. Haplotype I (fig. 5, H1) includes samples of bees from the Vuchkovskaya line of Transcarpathia, some samples from the apiaries of Feodosia and the village of Ukromnoye, Simferopol district, as well as all samples of wild bees caught near the Tankovoye village. Haplotype 2 (fig. 5, H2) combines samples of the Caucasian breed from the GenBank (KX819203.1+AY114466.1) with part of the samples from the apiaries of Feodosia and the village of Ukromnoe, Simferopol district, as well as Caucasian bees from the apiary hive of the private nursery "Orekhovod - practitioner". Haplotype 3 (fig. 5, H3) is represented by bee samples from the "Red Caves" of the Simferopol district. Haplotype 4 (fig. 5, H4) - Italian breed (L06178.1). Haplotype 5 (fig. 5, H5) - Central Russian breed (KJ396188.1).

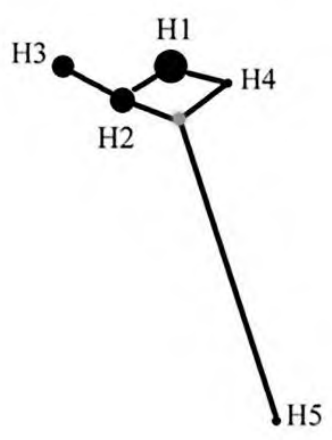

Fig. 5. Median network of haplotypes $(\mathrm{H})$ of bee samples from different regions of Crimea in comparison with A. mellifera carpatica, A. mellifera caucasica, A. mellifera ligustica, A. mellifera mellifera, constructed based on the nucleotide sequence of the mtDNA COI gene site. Circles separate haplotypes.

Analysis of the median network showed that wild bees from the swarm caught near the Tankovoye village is close to the Vuchkovskaya line of the Carpathian bee by mtDNA COI. The results of the analysis suggest that the sample of wild bees is a feral swarm that emerged from a nearby apiary, possibly formed on the basis of bee lines from Ukraine or southwestern Europe.

\section{Conclusions}

The performed morphometric analysis allows indicating the discrepancy between bees in samples from two geographic points and officially recognized breed standards. Thus, the results of morphometric studies of wild worker bees caught in the forest glades of the 
reserved forest massif in the vicinity of Sugut-Oba mountain (Burus) (Belogorsk region, Republic of Crimea) showed that the average value of the proboscis length of $A$. mellifera was in compliance with the standards of various species - Carpathian, Ukrainian steppe, Italian, and Carniolan.

The results of laboratory study along the length and width of the right fore wing also make it possible to note that they do not correspond to the existing breed standards.

The cubital index showed a wide range of variability between the minimum $(27.27 \%)$ and maximum (51.42\%) values of the limit. At the same time, the minimum value of the limit did not correspond to the accepted breed standards. The maximum value corresponded to the standards of the gray mountain Caucasian and yellow Caucasian breeds. As for the average value of the cubital index, in this case it can be noted that it corresponds only to the standard of the Italian breed.

In terms of the prevalence of indicators of discoidal displacement, the bees in the samples did not meet the accepted breed standards.

The phenotypic assessment of bees in the samples allowed registering one phenotype characterized by morphotype $\mathrm{O}$ (light brown coloration of chitinous integuments on the abdomen) and a narrow hairline $\mathrm{f}$. The presence of this phenotype characterizes compliance with the breed standards of gray mountain Caucasian, Carpathian or Carnolian bees, i.e. breeds with a gray abdomen.

Analysis of the median network showed that wild bees from the vicinity of the Tankovoe village is close to the Vuchkovskaya line of the Carpathian bee by mtDNA COI. The results of the analysis suggest that these bees from this origin represent a feral swarm that emerged from a nearby apiary formed, possibly, on the basis of bee lines from Ukraine or southwestern Europe.

Thus, many years of expeditionary and laboratory research in the field of identifying purebred bees on the territory of the Crimean Peninsula made it possible to find some local points where wild honey bees live. Research carried out using classical methods made it possible to identify them as a group of honey bees that do not correspond, mostly, to the morphological characteristics of officially recognized breed standards. Of course, the presented result can be assessed as the result of the expansion of other breeds in this region. However, according to phenotype, the bees in the samples were characterized by the same coloration of chitinous integuments and the width of the hairline. And this, primarily implies the presence of a single genetic basis that determines these features.

"The studies were carried out with the financial support of the Russian Foundation for Basic Research, project No. 20-316-80033, on the topic "Isolation and testing of a new line of honey bees from wild bees in the mountain-forest zone of Crimea", competition code "mol_ev_a".

\section{References}

1. Büchler R, Costa C, Hatjina F et al 2014 The influence of genetic origin and its Interaction with environmental effects on the survival of Apis mellifera L. colonies in Europe J. Apicultural Research 53 205-214 DOI: 10.3896/IBRA.1.53.2.03

2. Dussaubat C, Brunet J-L, Higes M et al 2012 Gut Pathology and Responses to the Microsporidium Nosema ceranae In the Honey Bee Apis mellifera PLoS ONE 7(5) 11 DOI: 10.1371/journal.pone.0037017

3. Steinhauer N A, Rennich K, Wilson M E et al 2014 A national survey of managed honey bee 2012-2013 annual colony losses in the USA: results from the Bee Informed Partnership J. Apicultural Research 53(1) 1-18 DOI: 10.3896/IBRA.1.53.1.01

4. Chauzat M P, Jacques A, Laurent M, Bougeard S, Hendrikx P and Ribière-Chabert M 
2016 Risk indicators affecting honeybee colony survival in Europe: one year of surveillance Apidologie 47 348-378 DOI: 10.1007/s13592-016-0440-z

5. Fernandez N and Coineau Y 2006 Varroa the serial bee killer mite: to be able to combat her, one must properly understand her (Biarritz: Atlantica) p 259 ISBN-13: 978-2843949500

6. Fenoy S, Rueda C, Higes M, Martín-Hernández R and del Aguila C 2009 High-level resistance of Nosema ceranae, a parasite of the honeybee, to temperature and desiccation Appl. Environ. Microbiol. 75 6886-89 DOI: 10.1128/AEM.01025-09

7. De la Rúa P, Jaffé R, Dall'Olio R, Serrano J and Muñoz I 2009 Biodiversity, conservation and current threats to European honeybees Apidologie 40(3) 263-284 DOI: 10.1051/apido/2009027

8. Pritchard D J 2008 Nature reserves and honey bees Conservation Land Management 6 20 DOI: 10.1007/s10841-013-9609-1

9. Bodur C, Kence M and Kence A 2007 Genetic structure of honeybee Apis mellifera L. (Hymenoptera: Apidae) populations of Turkey inferred from microsatellite analysis $J$. Apic. Res. 46 50-56 DOI: 10.1080/00218839.2007.11101366

10. Neumann P and Carreck N L 2010 Honey bee colony losses J. Apic. Res. 49 1-6 DOI: 10.3896/IBRA.1.49.1.01

11. Le Conte Y and Navajas M 2008 Climate change: impact on honey bee populations and disease In Climate change: impact on the epidemiology and control of animal diseases Rev. sci. tech. Off. int. Epiz. 27 499-510 PMID: 18819674

12. Jensen A B, Palmer K A, Boomsma J J and Pedersen B V 2005 Varying degrees of Apis mellifera ligustica introgression in protected populations of the black honeybee Apis mellifera mellifera, in northwest Europe Molecular Ecology 14(1) 93-106 DOI: 10.1111/j.1365- 294X.2004.02399.x

13. Borodachev A V 2016 State Scientific Research Institute of Beekeeping of the Russian Agricultural Academy Collection of scientific research works on beekeeping (Rybnoye: FSBSI "Scientific Research Institute of Beekeeping") p 149

14. Ivashov A V, Bykova T O, Sattarov V N and Mannapov A G 2017 Honey potential and number of bee families in the Republic of Crimea Beekeeping journal 10 18-21 ISSN: 0369-8629

15. Mannapov A G and Sattarov V N 2018 Some reflections on the method of preparing bee samples for morphometric measurements Beekeeping journal 10 20-22 ISSN: 0369-8629

16. Borodachev A V, Burmistrov A N, Kasyanov A I et al 2006 Methods of scientific research in beekeeping Methodical recommendations (Rybnoe: Scientific Research Institute of Beekeeping) p 154 ISBN 5-900205-35-5

17. Bykova T O, Triseleva T A, Ivashov A V and Safonkin A F 2016 To the assessment of morphogenetic diversity of the honey bee Apis mellifera L. from the mountain-forest zone of the Crimea Izvestiya RAS. Biology 6 625-630 DOI: 10.1134/S1062359016060054

18. Tamura K, Peterson D, Peterson N, Stecher G, Nei M and Kumar S 2011 MEGA5: molecular evolutionary genetics analysis using maximum likelihood, evolutionary distance, and maximum parsimony methods Mol. Biol. Evol 28 2731-39 DOI: 10.1093/molbev/msr121

19. Talalaiko A S, Bykova T O, Ivashov A V and Sattarov V N 2018 Comparative characteristics of honey bees (Apis mellifera) of the Foothill forest-steppe zone of the 
Crimea Ecosystems journal 15 (45) 137-141 DOI 10.37279/2414-4738

20. Borodachev A V and Savushkina L N 2012 Conservation and rational use of the gene pool of honey bee breeds Beekeeping journal 4 3-5 ISSN 0369-8629

21. Safonkin A F, Triseleva T A and Bykova T O 2019 Intraracial diversity of the Carpathian race of the honey bee (Apis mellifera carpatica) Izvestiya RAS. Biology 5 524-532 DOI: 10.1134/S1062359019050091 